\title{
JOURNAL.RU
}

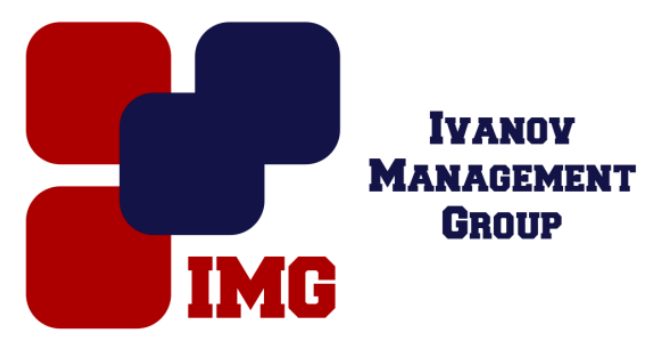

Коновалова Ю.Н. Набережночелнинский колледж искусств Набережные Челны, Россия

doi: $10.18411 / 1 \mathrm{j}-31-05-2017-24$

idsp 000001:1j-31-05-2017-24

\section{Развитие средствами физической культуры профессионально значимого психического качества у музыкантов-инструменталистов}

\section{Аннотация}

В статье автор рассматривает психическую подготовку музыкантов, как неотъемлемую часть их профессиональной подготовки. Автором выявленные профессионально значимые психические качества музыкантов и предложены варианты применения средств физической культуры для их развития.

Ключевые слова: профессиональная деятельность музыкантов, психическая подготовка, профессионально значимые психические качества.

Актуальность исследования. Концертная деятельность является квинтэссенцией всей профессиональной подготовки музыканта, а залогом успешности этой деятельности служит внешнее телесное состояние исполнителя и его внутренняя психическая готовность [5].

В профессиональной деятельности музыканта чрезвычайно важное значение имеет психическая подготовка. Так перед выступлением музыканты часто испытывают сценическое волнение, сходное с предстартовым состоянием спортсмена, которое вызывает значительное нервно-психическое утомление и ряд связанных с ним отрицательных явлений, к числу которых, прежде всего, необходимо отнести провалы памяти и потеря концентрации внимания $[1,2,4]$.

В настоящее время крайне мало внимания уделяют психической подготовке музыкантов в процессе его профессионального обучения. Практически отсутствуют или редко используются методики целенаправленного воздействия на психическое состояние исполнителя, в том числе и средствами 
физической культуры, которые являются наиболее эффективным инструментом развития профессионально значимых психических качеств музыканта $[6,7]$.

Целью нашего исследования является изучение возможности применения средств физической культуры для развития профессионально значимого психического качеств музыканта «Память».

Результаты исследования. Для достижения исполнительского мастерства музыкантам помимо хорошего физического здравья и физической подготовленности необходимо иметь достаточный уровень развития психических качеств. Основным психическим профессионально важным качеством, которые рассматривается в исследовании, является «Память».

Память в музыкальной профессиональной деятельности имеет важное значение, так, например, при работе с музыкальным материалом, в процессе заучивания информация поступает в долговременную память через своеобразный «буфер» оперативной памяти. В процессе разучивания музыкального материала постепенно происходит понижение требований к этому «буферу» оперативной памяти и повышение их к долговременной памяти. Другим важным проявлением этого качества в профессиональной музыкальной деятельности является двигательная память, которая является основой для постановки исполнительского аппарата [3].

Для развития основных психических качеств, мы определили наиболее эффективное средство, применение которого возможно в рамках реализации учебного процесса в музыкальных ССУЗ, физическая культура.

Занятия физической культурой в средних специальных учебных заведениях проводятся на 1-3 курсах (1-6 семестр), а также в первом семестре 4 курса. То есть занятия физической культурой проводятся на протяжении всего периода обучения, однако каждому курсу соответствует определенный этап, на котором решаются конкретные задачи: 1 год обучения (1 курс) - этап здоровьесбережения. 2 год обучения (2 курс) - этап здоровьеформирования. 3 год обучения (3 курс) - этап профессионального формирования. 4 год обучения (4 курс) - этап профессионального становления [8].

При проведении исследования показателя профессионально значимого психического качества «Память» мы использовали тест «Оперативная память». Тестирование проводилось, согласно общепринятой методике.

Статистические показатели результатов в тесте на оперативную память на первом этапе у девушек из экспериментальной и контрольной групп равнялись 


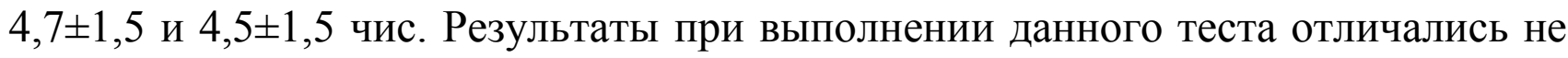
существенно $(\mathrm{p}>0,05)$.

Два следующих этапа также не выявили преимущество в развитии данного

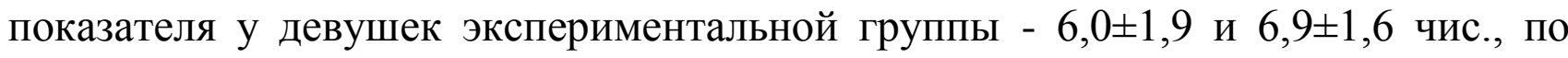

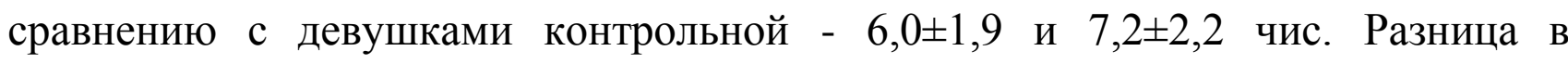
результатах является статистически незначимой $(\mathrm{p}>0,05)$. Продолжение экспериментальной работы с девушками на 4 этапе привело к выраженному приросту этого показателя. Так, среднегрупповые результаты в экспериментальной группе составили $9,0 \pm 1,5$ чис., а в контрольной группе всего $7,9 \pm 1,9$ чис. Показатель оперативной памяти у девушек экспериментальной группы вырос более значимо и с высокой степенью достоверности $(\mathrm{p}<0,05)$. Улучшение за период исследования в данном показателе в экспериментальной группе составило 4,4 чис., а в контрольной группе - 3,4 чис. Увеличение разности между среднеарифметическими показателями исследуемых групп к концу эксперимента достигло 1,1 чис., что является статистически значимым $(\mathrm{p}<0,05)$.

Таким образом, на основании изложенного выше можно сделать вывод, о том, что прирост исследуемого показателя «Память» произошел во всех группах, однако в экспериментальных группах более выраженно, и это в первую очередь связано с применением широкого арсенала средств физической культуры, реализуемых в рамках учебного процесса, и целенаправленных на развитие не только физических, но и психических качеств, являясь наиболее эффективным инструментом профессиональной подготовки музыканта. 
1. Коновалов, И. Е. Эффективность внедрения системы современного физического воспитания в ССУЗ музыкального профиля / И.Е. Коновалов // Теория и практика физической культуры. - 2011. - №12. - С.44-47.

2. Коновалов, И. Е. Основные направления формирования мотивации у студентов музыкальных ССУЗ к занятиям физической культурой / И.Е. Коновалов // Фундаментальные исследования. - 2011. - №4. - С.23-28.

3. Коновалов, И. Е. Особенности физического воспитания студентов музыкальных средних специальных учебных заведений: состояние и проблемы / И.Е. Коновалов // Физическая культура: воспитание, образование, тренировка. - 2011. - №3. - С.25-30.

4. Коновалов, И. Е. Структура и программно-содержательное обеспечение системы современного физического воспитания студентов музыкальных средних специальных учебных заведений : монография / И.Е. Коновалов. - М. : Флинта, 2011. - 352 с.

5. Коновалов, И. Е. Новые формы организации процесса физического воспитания в музыкальных ССУЗ / И.Е. Коновалов // Культура физическая и здоровье. - 2012. - № 6(42). - C.43-45.

6. Коновалов, И.Е. Структура и программно-содержательное обеспечение системы современного физического воспитания студентов музыкальных ССУЗ: автореферат дис.... доктора пед. наук. - Набережные Челны: Поволжская ГАФКСиТ, 2012. - 46 с.

7. Коновалов, И. Е. Модель системы современного физического воспитания студентов музыкальных средних специальных учебных заведений / И.Е. Коновалов // Теория и практика общественного развития. - 2013. - № 5. - С.152-155.

8. Коновалов, И. Е. Организация и содержание современной системы физического воспитания музыкантов средних специальных учебных заведений / И.Е. Коновалов // European Social Science Journal. - 2013. - №8(35). - Том 2. - C.121-127. 